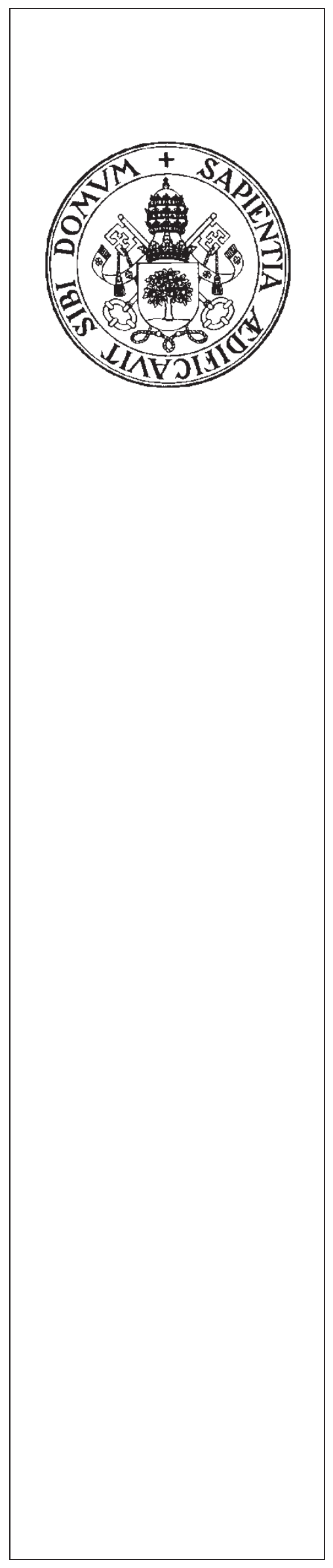

UNIVERSIDAD DE VALLADOLID

TRABAJO FIN DE MASTER

MASTER EN INVESTIGACIÓN

INGENIERÍA DE PROCESOS Y SISTEMAS

OPTIMIZATION OF THE ENZYMATIC HYDROLYSIS CONDITIONS OF STEAMEXPLODED WHEAT STRAW FOR MAXIMUM GLUCOSE AND XYLOSE RECOVERY 

SUSANA LUCAS YAGÜE y $\mathrm{M}^{\mathrm{a}}$ TERESA GARCIA CUBERO, profesoras del Departamento de Ingeniería Química y Tecnología del Medio Ambiente de la Universidad de Valladolid, INFORMAN:

Que D ${ }^{a}$ MÓNICA MARCOS ENRÍQUEZ ha realizado bajo nuestra dirección el Trabajo Fin de Master, del Master en Investigación Ingeniería de Procesos y Sistemas, titulado OPTIMIZATIÓN OF THE ENZYMATIC HYDROLYSIS CONDITIONS OF STEAM-EXPLODED WHEAT STRAW FOR MAXIMUM GLUCOSE AND XYLOSE RECOVERY.

Valladolid, 5 de Julio de 2012
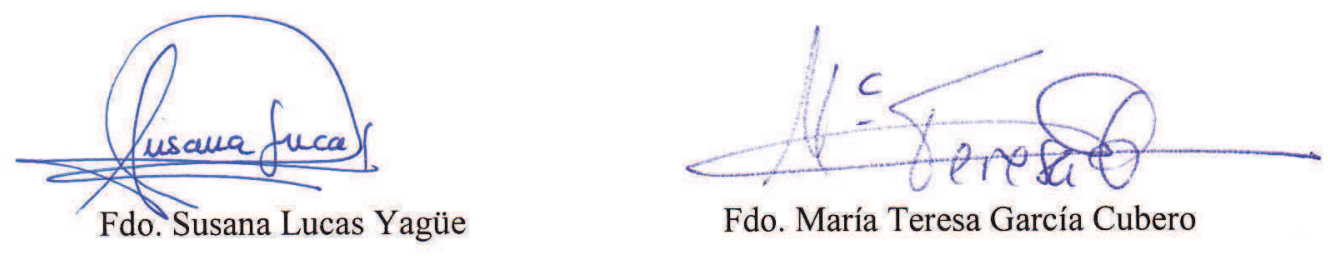

Fdo. María Teresa García Cubero 
Reunido el Tribunal designado por el Comité Académico del Master en Investigación en Ingeniería de Procesos y Sistemas, para la evaluación de los Trabajos Fin de Master, y después de estudiar la memoria y atender a la defensa del trabajo "OPTIMIZATIÓN OF THE ENZYMATIC HYDROLYSIS CONDITIONS OF STEAMEXPLODED WHEAT STRAW FOR MAXIMUM GLUCOSE AND XYLOSE RECOVERY”, presentado por el alumno $\mathrm{D}^{\mathrm{a}}$ MÓNICA MARCOS ENRÍQUEZ, decidió otorgarle la calificación de

Valladolid, de Julio de 2012

El Presidente

El Secretario

Fdo.:

Fdo.:

Vocal

Fdo.: ********************* 



\title{
OPTIMIZATION OF THE ENZYMATIC HYDROLYSIS CONDITIONS OF STEAM-EXPLODED WHEAT STRAW FOR MAXIMUM GLUCOSE AND XYLOSE RECOVERY
}

\author{
Publicado por Mónica Marcos et al. en Journal of Chemical Technology and Biotechnology \\ Department of Chemical Engineering and Environmental Technology, \\ University of Valladolid, Dr. Mergelina s/n, 47011 Valladolid, Spain
}

\begin{abstract}
The enzymatic hydrolysis of steam-exploded wheat straw using commercial enzyme complexes has been studied. A cellulase enzyme complex (Accellerase 1500), along with specific xylanase complements (Accellerase-XC and Accellerase-XY) provided by Genencor, have been used to enhance glucose and xylose recovery. A systematic study with response surface methodology (RSM) was used to check the effect of the operating conditions: $\mathrm{pH}(4-5)$, temperature $\left(50-60{ }^{\circ} \mathrm{C}\right)$ and enzyme/substrate ratio $(0.1-$ $0.5 \mathrm{~mL} \mathrm{~g}^{-1}$ cellulose) on the enzymatic hydrolysis with Acellerase 1500 to maximize the sugar yield. Xylanases were used as complements to increase the release of xylose.
\end{abstract}

Statistical results from ANOVA analysis demonstrated that the enzymatic hydrolysis was clearly improved by temperature and enzyme/substrate ratio. The optimum conditions for higher glucose and xylose releases were obtained with the higher enzyme dosage ratio $\left(0.5 \mathrm{~mL} \mathrm{~g}^{-1}\right.$ cellulose $), 50{ }^{\circ} \mathrm{C}$ and $\mathrm{pH} 4$.

Model validation at optimum operating conditions showed good agreement between the experimental results and the predicted responses for a confidence level of $95 \%$. The use of the xylanase complements, Accellerase- $X Y$ (accessory xylanase enzyme complex) and Accellerase-XC (accessory xylanase/cellulase enzyme complex), increases the conversion of hemicellulose. Accellerase-XC supplementation was more effective, obtaining an increase in yields of glucose and xylose of $11.8 \%$ and $23.6 \%$, respectively, using a dosage of $0.125 \mathrm{~mL} \mathrm{~g}^{-1}$ cellulose.

\section{INTRODUCTION}

Lignocellulosic materials, such as agricultural and forest residues, grasses, municipal wastes and other low-cost biomasses, are an abundant, cheap and renewable source of sugar substrate that could be fermented to ethanol. Its use can significantly reduce the cost of raw materials (compared with corn) for ethanol production (Lin Y et al., 2006).

Wheat straw is one of the most abundant crop residues in European countries with a production of 170 million tonnes per year, and seems to be the cheapest and the most useful raw material for ethanol production (Tabka MG et al., 2006). Wheat straw is composed of a mixture of cellulose and hemicellulose (45\% and $30 \%$, respectively) that are bound to lignin (approx. $25 \%$ $\mathrm{w} / \mathrm{w} \mathrm{DM}$ ) by hydrogen and covalent bonds. Cellulose is a crystalline linear polymer composed of thousands of D-glucose linked by $\beta$-(1,4)- glycosidic bonds. Hemicellulose is an amorphous and partly crystalline polymer, formed mostly of $\beta-(1,4)$-xylose. Lignin is an aromatic polymer, containing phenolic residues, that binds the fibres together (Lin Y et al., 2006; Zaldivar J et al., 2001).Cellulose and hemicellulose can be hydrolysed to sugars, which can be fermented to ethanol. Lignin does not contribute to fermentable carbon sources because there is no known microorganism able to transform it for ethanol production (Galbe M et al., 2002).

In the conversion of lignocellulosic materials into ethanol, a pretreatment step is therefore included because of the high crystallinity of cellulose and the presence of lignin, which makes cellulose recalcitrant to degradation (Wingren et al., 2005). The pretreatment step should improve the accessibility to hydrolytic enzymes while avoiding the degradation of solubilized hemicellulose and cellulose. Sugar degradation not only decreases the final ethanol yield, but also results in degradation products that are inhibitory to the yeast used in the subsequent fermentation (Öhgren et al., 2007). Among the pretreatments, steam explosion is one of the most cost effective and widely used for wheat straw (Gusakov et al., 2007; Berlin et al., 2007; Zhou et al., 2009). 
At least three categories of enzymes are necessary to convert cellulose into soluble sugars. These include endoglucanase (EG) (EC 3.2.1.4), which hydrolyses internal $\beta$-1,4-glucosidic bonds randomly in the cellulose chain; cellobiohydrolase (CBH) (EC 3.2.1.91), which moves progressively along the cellulose chain and cleaves off cellobiose units from the ends of the chain; and $\beta$-glucosidase (BG) (EC 3.2.1.21), which converts cellobiose and soluble cellodextrins into glucose. All these enzymes work synergistically to hydrolyse cellulose.10 In addition, there are also a number of enzymes that attack hemicellulose, such as xylanase, $\beta$ xylosidase, acetylsterase, etc. The conjugated action of cellulases and hemicelluloses raises the rate of enzymatic hydrolysis and results in a higher ultimate sugar production (Sun and Cheng, 2002, Alvira et al., 2011). The hydrolytic efficiency and the cost of enzymes are the major factors that restrict the commercialization of the bioethanol production process (Sun $Y$ et al., 2002; Berlin A et al., 2007). The hydrolytic efficiency of a multi-enzyme mixture depends on the properties of individual enzymes, their ratio in the multi-enzyme cocktail, pretreatment technology and type of substrate (Berlin A et al., 2007; Zhou K et al., 2009; Banerjee G et al., 2010).

Despite its high potential, there are not manystudies that combine cellulases andxylanases inthehydrolysis of steam-explodedwheat straw. Among published research, cellulases and xylanases from $T$. reesei were used in the enzymatic hydrolysis of steam-exploded wheat straw (Tabka MG et al., 2006). Enzymatic microassays were used to analyse the role of endoxylanase and $\alpha$-L-arabinofuranosidade (hemicellulolytic enzymes) in combination with commercial cellulases (Alvira $P$ et al., 2011). In this work, fixed operating conditions were used. Optimization of enzyme loadings and operating conditions can improve the hydrolysis step making the process more cost-effective.

Response surface methodology (RSM) is a powerful tool to ascertain the optimum operating conditions for enzymatic hydrolysis, by combining experimental designs and interpolation by polynomial equations (first or second order) (Fang H et al., 2010; Tu M et al., 2009).

In this work, the optimization of the enzymatic hydrolysis of steam-exploded wheat straw with a novel cellulase enzyme complex (Accellerase 1500 from Genencor), based on RSM methodology and the multiple regression method, was carried out. The aim of the optimization process was to find an optimal combination of operating factors that maximize the sugar yield (higher concentration of fermentable sugars to be converted into ethanol). Three independent variables (temperature, $\mathrm{pH}$ and enzyme/substrate ratio) were selected for the RSM design and a multiple regression method, taking into account the main interactions of the selected variables on the response (sugars release), was proposed. The use of supplementation enzymes, such as accessory xylanase enzyme complex (Acellerase-XC,Genencor) and accessory xylanase/cellulase enzyme complex (Acellerase- XY,Genencor), both showing xylanase activity, has been included to evaluate their effect and potential application in steamexploded wheat straw saccharification.

\section{MATERIALS AND METHODS}

\subsection{Substrates and pretreatment}

Wheat straw was kindly donated by the Castilla \& León Institute of Technological Agriculture. The straw was ground in a blender and sieved to obtain a particle size of $20 \mathrm{~mm}$.

Steam explosion pretreatment of wheat straw was carried out in a $5 \mathrm{~L}$ stainless steel batch reactor, in which the straw was loaded at the top and heated to the desired temperature $(210$ $\left.{ }^{\circ} \mathrm{C}\right)$ with saturated steam injected directly into the reactor. After the pre-set residence time $(10$ $\mathrm{min}$ ), the steam-treated biomass was released from the reactor by rapid depressurisation of the vessel. A complete description of the experimental set-up and the optimization of pretreatment operating conditions to maximize sugar yield have been detailed in previous work (García MT et al., 2008; García-Cubero MT et al., 2010; Bellido C et al., 2011). After pretreatment the product was washed with warm water and the residual solid separated by filtration. The solid portion was dried in an oven at $45{ }^{\circ} \mathrm{C}$, stored in a freezer and used for enzymatic hydrolysis. The compositions $(\% \mathrm{w} / \mathrm{w})$ of raw and pre-treated material were determined. Raw wheat straw 
contained: cellulose (as glucose) 36.3\%, hemicellulose (as xylose) 19.1\%, acid insoluble lignin (AIL) $21.3 \%$, acid soluble lignin (ASL) $6.4 \%$ and ash $6.9 \%$. In the case of pretreated wheat straw, the composition was: cellulose (as glucose) $42.2 \%$, hemicellulose (as xylose) $16.8 \%$, acid insoluble lignin (AIL) $18.4 \%$, acid soluble lignin (ASL) $1.3 \%$ and ash $4.3 \%$.

\subsection{Enzymes}

A commercial cellulase preparation (Accellerase 1500) has been studied in supplementation assays with complements XC and XY. These enzymes were kindly donated by Genencor.

Accellerase 1500 is an enzyme complex containing multiple enzyme activities, mainly exoglucanase, endoglucanase, hemicellulase and $\beta$-glucosidase. The Accellerase XC complex is designed to supplement cellulases and exhibits activity towards xylan (xylanase activity) and glucan (endoglucanase activity). On the other hand, the Accellerase XY complex presents high xylanase activity.

According to the enzyme information sheet supplied by Genencor, the best operational stability for Accellerase 1500 was found in the temperature range 50 to $65^{\circ} \mathrm{C}$ and $\mathrm{pH}$ range 4 to 5 . An Accellerase 1500 dosage ratio of $0.1-0.5 \mathrm{~mL}$ per gram of cellulose is recommended as a starting point for the enzyme dosage. Accellerase $X C$ has an optimum temperature range of $45-65^{\circ} \mathrm{C}$ and an optimal pH of 3.5-6.5, whereas for Accellerase $\mathrm{XY}$ the temperature should be between 50 and $75{ }^{\circ} \mathrm{C}$ and $\mathrm{pH} 4.5-7.0$. The recommended dosage ratios for $\mathrm{XC}$ and $\mathrm{XY}$ enzyme complexes are $0.025-0.25 \mathrm{~mL}$ per gram of cellulose and 0.01 to $0.1 \mathrm{~mL}$ per gram of cellulose, respectively.

\subsection{Enzymatic hydrolysis}

Enzymatic hydrolysis experiments with pretreated wheat straw were conducted under different operating conditions using Accellerase 1500, kindly donated by Genencor. All the experiments were carried out at $3 \mathrm{w} / \mathrm{w} \%$ DM (dry matter) on a rotary incubator at $300 \mathrm{rpm}$ for a period of 96 h. The experimental variables studied in this work were enzyme/substrate ratio, $\mathrm{pH}$ and temperature when Accellerase 1500 was used (Table 1). Once the operating conditions with Accellerase 1500 were optimized, several tests for the enzymatic hydrolysis with $\mathrm{XC}$ and $\mathrm{XY}$ complements were carried out at different dosage ratios and $\mathrm{pH}$ levels. After the hydrolysis phase, $750 \mu \mathrm{L}$ samples were withdrawn, passed through a $0.22 \mu \mathrm{m}$ filter and stored for carbohydrate analysis.

\subsection{Analytical methods}

Acid insoluble lignin, acid soluble lignin, cellulose and hemicelluloses in the raw material were estimated following NREL laboratory analytical procedures, Determination of Structural Carbohydrates and Lignin in Biomass (NREL 2008). On the other hand, a Bio-Rad HPX-87P ion-exclusion column was used to measure carbohydrate concentration. The mobile phase was water at a flow ratio of $0.6 \mathrm{~mL} \mathrm{~min}-1$ and $60^{\circ} \mathrm{C}$. The detector was based on refraction index measurement (Waters 2414 refractive index detector).

\subsection{Experimental design}

Response surface methodology (RSM) was used for modelling the enzymatic hydrolysis of pretreated wheat straw with Accellerase 1500. Glucose and xylose production (expressed in \% w/w DM) were selected as the response (dependent variable), while the Accellerase 1500 dosage ratio ( $\mathrm{mL}$ enzyme per gram cellulose), $\mathrm{pH}$ and temperature were considered as independent variables. Every variable was set to two or three levels. The set of experimental runs carried out are summarized in Table 1. All experiments were conducted in triplicate and the mean values of glucose and xylose were taken as response. 


\begin{tabular}{|c|c|c|c|c|c|}
\hline \multirow[b]{2}{*}{ Treatment } & \multicolumn{3}{|c|}{ EXPERIMENTAL VARIABLES } & \multicolumn{2}{|c|}{ RESPONSES } \\
\hline & $\mathrm{pH}$ & $\begin{array}{c}\text { Temperature } \\
\left({ }^{\circ} \mathrm{C}\right)\end{array}$ & $\begin{array}{c}\text { Ratio } \\
\text { (mL/g } / \text { cellulose })\end{array}$ & $\begin{array}{c}\text { Glucose } \\
\left(\mathrm{g} / 100 \mathrm{~g}_{\mathrm{DM}}\right)\end{array}$ & $\begin{array}{c}\text { Xylose } \\
\left(g / 100 g_{D M^{*}}\right)\end{array}$ \\
\hline 1 & $4(-1)$ & $50(-1)$ & $0.1(-1)$ & $18.0 \pm 0.4$ & $2.9 \pm 0.3$ \\
\hline 2 & $5(1)$ & $50(-1)$ & $0.1(-1)$ & $19.6 \pm 0.7$ & $2.7 \pm 0.4$ \\
\hline 3 & $4(-1)$ & $57(0)$ & $0.1(-1)$ & $13.5 \pm 0.4$ & $3.2 \pm 0.1$ \\
\hline 4 & $5(1)$ & $57(0)$ & $0.1(-1)$ & $12.2 \pm 1.1$ & $2.1 \pm 0.7$ \\
\hline 5 & $4(-1)$ & $60(1)$ & $0.1(-1)$ & $7.6 \pm 1.3$ & $2.7 \pm 0.2$ \\
\hline 6 & $5(1)$ & $60(1)$ & $0.1(-1)$ & $6.2 \pm 0.9$ & $1.7 \pm 0.5$ \\
\hline 7 & $4(-1)$ & $50(-1)$ & $0.3(0)$ & $29.3 \pm 0.8$ & $4.0 \pm 0.3$ \\
\hline 8 & $5(1)$ & $50(-1)$ & $0.3(0)$ & $28.1 \pm 0.6$ & $3.3 \pm 0.4$ \\
\hline 9 & $4(-1)$ & $57(0)$ & $0.3(0)$ & $19.0 \pm 1.0$ & $3.5 \pm 0.7$ \\
\hline 10 & $5(1)$ & $57(0)$ & $0.3(0)$ & $21.3 \pm 1.7$ & $3.4 \pm 0.3$ \\
\hline 11 & $4(-1)$ & 60 (1) & $0.3(0)$ & $12.7 \pm 1.5$ & $3.3 \pm 0.5$ \\
\hline 12 & $5(1)$ & 60 (1) & $0.3(0)$ & $11.1 \pm 1.3$ & $2.4 \pm 0.9$ \\
\hline 13 & $4(-1)$ & $50(-1)$ & $0.5(1)$ & $34.2 \pm 0.5$ & $4.6 \pm 0.6$ \\
\hline 14 & $5(1)$ & $50(-1)$ & $0.5(1)$ & $33.1 \pm 1.7$ & $4.1 \pm 0.2$ \\
\hline 15 & $4(-1)$ & $57(0)$ & 0.5 (1) & $22.2 \pm 2.1$ & $4.1 \pm 0.5$ \\
\hline 16 & $5(1)$ & $57(0)$ & 0.5 ( 1) & $26.2 \pm 0.9$ & $3.5 \pm 0.4$ \\
\hline 17 & $4(-1)$ & $60(1)$ & $0.5(1)$ & $16.2 \pm 0.8$ & $3.8 \pm 0.3$ \\
\hline 18 & $5(1)$ & $60(1)$ & $0.5(1)$ & $12.5 \pm 0.4$ & $2.7 \pm 0.4$ \\
\hline
\end{tabular}

*DM: Dry matter

Value in parenthesis represents coded factor levels

Table 1 Design matrix for the three independent variables in real and coded values and glucose and xylose concentrations obtained after $96 \mathrm{~h}$ hydrolysis

Analysis of the influence of variables on enzymatic hydrolysis was developed using the multiple regression method and the professional software STATGRAPHICS Plus. Multiple regression analysis allows a regression model between one dependent variable (response) and one or more independent variables (factors) to be calculated. In this case, a quadratic polynomial equation was proposed to describe the mathematical relationship between the response (glucose or xylose production) and the factors (enzyme ratio, $\mathrm{pH}$ and temperature). Multiple regression methods use least squares to estimate the regression model and hence the $R^{2}$ coefficient. Solving the regression equation, an optimum value of the selected variables was obtained using STATGRAPHICS Plus, and a confirmatory experiment was carried out to verify this optimum.

The effect of $X C$ and $X Y$ supplementation on the efficiency of enzymatic hydrolysis was analyzed using a statistical analysis based on Student's $t$-test to corroborate the statistical significance of the results. Student's $t$-test is a statistical technique used for determining the probability that two populations are the same with respect to the variable tested. In this work the $t$-test makes it possible to detect whether the $\mathrm{XC}$ and $\mathrm{XY}$ loadings and the $\mathrm{pH}$ are significant factors for enzymatic hydrolysis within the range of operating conditions tested (Table 5 and Table 6). The confidence level used in this significance test was $95 \%$. A $P$-value of less than 0.05 means that the samples compared are significantly different according to the factor $(\mathrm{pH}$ or enzyme loading) analyzed.

\section{RESULTS AND DISCUSSION}

\subsection{Enzymatic hydrolysis with Accellerase 1500}

\section{Preliminary experiments}


Preliminary experiments were carried out to screen the appropriate parameters and to determine the experimental domain. As mentioned previously, enzyme/substrate ratio, $\mathrm{pH}$ and temperature were the operating parameters studied. The dry matter content, the agitation rate and the reaction time were fixed on the basis of previous tests (data not shown) and a review of the literature. A dry matter content of $3 \% \mathrm{w} / \mathrm{w}$ DM was selected for all the experiments in order to overcome problems occurring under industrial-like conditions such as end-product inhibition, caused by the high glucose concentration (resulting from hydrolysis at high substrate concentration), and inefficient mass transfer associated with mixing problems( Sun $Y$ et al., 2002; Fang $\mathrm{H}$ et al., 2010; Lin L et al., 2010). Similar dry matter contents (2-5\%) have been used elsewhere in enzymatic hydrolysis of lignocellulosic materials (Alvira P et al., 2011). The level of agitation was found to be insignificant for glucose and xylose release when a low percentage of dry-matter was used for enzymatic hydrolysis experiments. A similar result was found in literature for the optimization of enzymatic hydrolysis of steam-exploded corn stover (Fang $\mathrm{H}$ et al., 2010). A sufficiently high agitation rate of $300 \mathrm{rpm}$ was considered in this study in order to avoid mass transfer limitations and to ensure suitable mixing. Although reaction time has been demonstrated to have a relatively strong influence on the yield of enzymatic hydrolysis, previous experiments have revealed no increase in glucose and xylose yield after 72 h. A similar trend for enzymatic hydrolysis of artificial biomass based on cellulose, hemicellulose and lignin using enzyme Accellerase 1500 was previously reported (Lin L eta al., 2010). For the above mentioned reasons, a reaction time of $96 \mathrm{~h}$ was fixed in order to counteract the effect of reaction time. Obviously, this variable is of great importance on an industrial scale in order to get smaller reaction volumes.

\section{Influence of temperature, $\mathrm{pH}$ and enzyme/substrate ratio}

Table 1 shows the results for glucose and xylose responses under the different operating conditions tested. Experiments were conducted at enzyme/substrate ratios from 0.1 to $0.5 \mathrm{~mL}$ enzyme per gram cellulose, $\mathrm{pH}$ was fixed at levels 4 and 5 and temperature ranged between 50 $\cdot \mathrm{C}$ and $60^{\circ} \mathrm{C}$.

For the enzyme/substrate ratio, at a fixed $\mathrm{pH}$ value and temperature, both glucose and xylose concentrations in hydrolysates increased with the enzyme ratio. As can be seen in Fig. 1, at pH $=4$ and $\mathrm{T}=50^{\circ} \mathrm{C}$, the production of glucose increased from $18.0 \pm 0.4 \mathrm{~g}$ per $100 \mathrm{gDM}$ for $\mathrm{a}$ dosage ratio of $0.1 \mathrm{~mL} \mathrm{~g}^{-1}$ cellulose to $34.2 \pm 0.5 \mathrm{~g}$ per $100 \mathrm{gDM}$ for a dosage ratio of $0.5 \mathrm{~mL} \mathrm{~g}^{-1}$ cellulose. For xylose the increase was from $2.9 \pm 0.3 \mathrm{~g}$ per $100 \mathrm{gDM}$ to $4.6 \pm 0.6 \mathrm{~g}$ per $100 \mathrm{gDM}$. This result is in agreement with that found in the literature: increasing the dosage of cellulase in the process, up to a certain point, can enhance the yield and ratio of hydrolysis, but would significantly increase the cost of the process.11 According to steam-exploded wheat straw characterization, cellulose and hemicellulose conversions were about $81 \%$ and $27 \%$, respectively, for the higher enzyme dosage.

An increase in temperature at fixed values of dosage ratio and $\mathrm{pH}$, leads to a reduction in sugar production (see Table 1). For example, at $\mathrm{pH}=4$ and a dosage ratio of $0.1 \mathrm{~mL} \mathrm{~g}^{-1}$ cellulose, the production of glucose decreased significantly from $18.0 \pm 0.4 \mathrm{~g}$ per $100 \mathrm{gDM}$ at $50 \circ \mathrm{C}$ to $7.6 \pm 1.3$ $\mathrm{g}$ per $100 \mathrm{gDM}$ at $60^{\circ} \mathrm{C}$. For xylose, the decrease was considerably lower, from $2.9 \pm 0.3 \mathrm{~g}$ per $100 \mathrm{gDM}$ to $2.7 \pm 0.2 \mathrm{~g}$ per $100 \mathrm{gDM}$.

Regarding the $\mathrm{pH}$ effect (Table 1), it can be concluded that an increase in $\mathrm{pH}$ value at a fixed dosage ratio and temperature, does not have a significant effect at $50{ }^{\circ} \mathrm{C}$. At a dosage ratio of $0.1 \mathrm{~mL} \mathrm{~g}^{-1}$ cellulose, the production of glucose and xylose remained approximately constant, with deviations lower than $8 \%$ at $\mathrm{pH} 4-5$.

Similar results were found by Cruz et al., 2011 for the optimization of enzymatic operating conditions of lignocellulosic material (banana peel ash) with Accellerase 1000 and Accellerase 1500 using a factorial design. They reported that the optimum temperature for the hydrolysis process was $50{ }^{\circ} \mathrm{C}$ in the temperature range $46-54^{\circ} \mathrm{C}$, while the $\mathrm{pH}$ value was the individual variable with the lowest significant effect in the process ( $\mathrm{pH}$ ranging from 4 to 5 ). 
From the analysis of these results, it can be concluded that the treatment with Accellerase 1500 resulted in superior release of glucose compared with xylose under specific conditions. As expected, treatment with Accellerase 1500 containing endoglucanase as the main activity resulted in high glucose yields, but gave only poor xylose liberation. High enzyme dosage ratio $\left(0.5 \mathrm{~mL} \mathrm{~g}^{-1}\right.$ cellulose, lower temperature $\left(50^{\circ} \mathrm{C}\right)$ and $\mathrm{pH}$ value $(4)$ are the optimum operating variables for improving glucose and xylose production in the tested range of hydrolysis conditions. This conclusion was tested with the RSM design described in the following section.
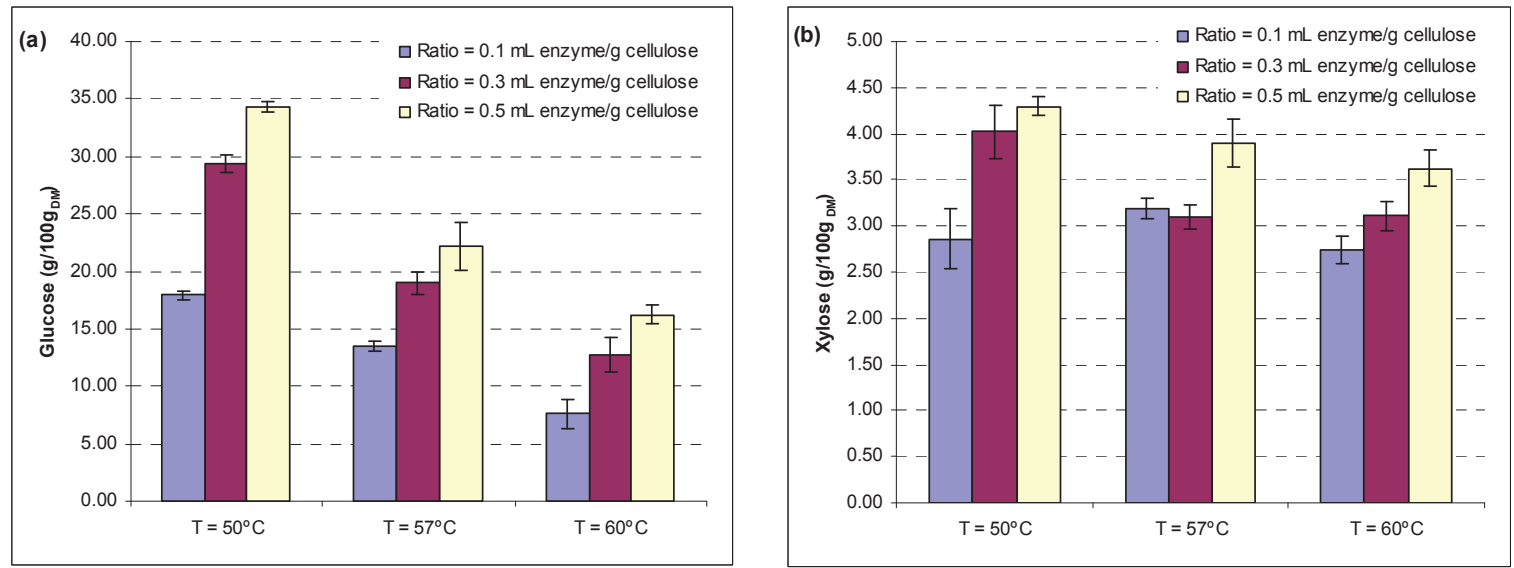

Figure 1 Effect of temperature and enzyme/substrate ratio on enzymatic hydrolysis of steam-exploded wheat straw with Accellerase $1500(\mathrm{pH}=4)$. a) Glucose concentration b) Xylose concentration. Enzymatic hydrolysis was carried with a $3 \%$ DM of steam-exploded wheat straw $\left(210^{\circ} \mathrm{C}, 10 \mathrm{~min}\right)$, at $50{ }^{\circ} \mathrm{C}, 300 \mathrm{rpm}$ and $96 \mathrm{~h}$

\subsection{RSM design for optimization of enzymatic hydrolysis}

The response of sugar production (glucose and xylose) in enzymatic hydrolysis, as a function of enzyme/substrate ratio, $\mathrm{pH}$ and temperature factors, was evaluated in an RSM design. Eighteen experiments carried out in triplicate were formed and modelled using STATGRAPHICS Plus software. All experiments were carried out under the following conditions: $3 \% \mathrm{w} / \mathrm{w} \mathrm{DM}, 96 \mathrm{~h}$ and $300 \mathrm{rpm}$. The coded levels of independent variables (enzyme/substrate ratio, $\mathrm{pH}$ and temperature) and the responses (glucose and xylose production) are listed in Table 1.

As can be seen in Table 1, glucose production varied from $6.2 \mathrm{~g}$ per 100gDM, when the lower enzyme/substrate ratio was considered, to $34.2 \mathrm{~g}$ per $100 \mathrm{gDM}$ for the higher ratio employed. The range for xylose released was from $1.7 \mathrm{~g}$ per $100 \mathrm{gDM}$ to $4.6 \mathrm{~g}$ per $100 \mathrm{gDM}$.

In order to screen crucial factors of the enzymatic hydrolysis process, several regression models can be applied. In this case, initial screen experiments, together with the ANOVA analysis, showed that a quadratic model should be proposed. The relationship between the responses and the variables was visualized by a response surface constructed according to the full model (Figs 2 and 3). Each 3D response surface plot show the relative effect of the two variables on the sugar production for a fixed $\mathrm{pH}$ value. Coefficients of the full model were analyzed for their significance and the insignificant ones were eliminated from the model by backward elimination. The reduced model was then adjusted and all the insignificant variables $(P$ value $>0.05)$ were excluded. The results are explained below. 


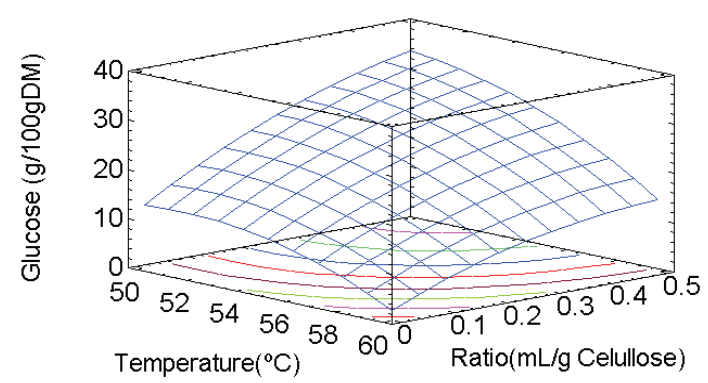

Fig. 2 Response surface plot of RSM design for the optimization of the enzymatic hydrolysis of steam-exploded wheat straw. Effect of temperature and enzyme/substrate ratio on glucose concentration at fixed $\mathrm{pH}=4$

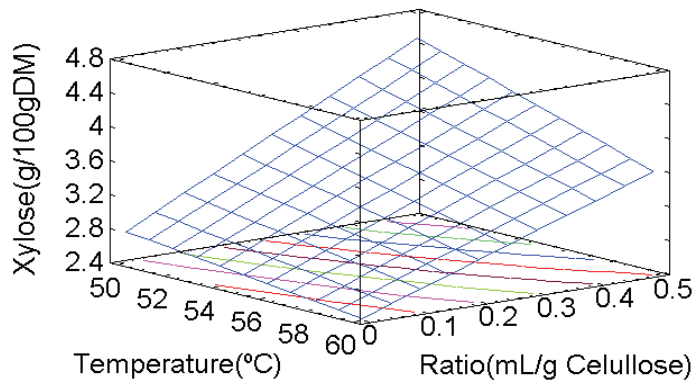

Fig. 3 Response surface plot of RSM design for the optimization of the enzymatic hydrolysis of steamexploded wheat straw. Effect of temperature and enzyme/substrate ratio on xylose concentration at fixed $\mathrm{pH}=4$

\section{Glucose release model}

The results from the statistical analysis of the surface response model used to optimize glucose production from wheat straw enzymatic hydrolysis with Accellerase 1500 are shown in Table 2.

\begin{tabular}{|c|c|c|c|c|}
\hline \multirow{2}{*}{ Variable } & \multicolumn{4}{|c|}{ GLUCOSE MODEL } \\
\hline & Coefficient & Standard error & T-stat & P-Value \\
\hline Constant & -392.71 & 68.06 & -5.77 & $<0.0001$ \\
\hline Temperature & 15.76 & 2.49 & 6.32 & $<0.0001$ \\
\hline Ratio & 153.05 & 19.23 & 7.96 & $<0.0001$ \\
\hline Ratio $\times$ Temperature & -1.760 & 0.321 & -5.49 & $<0.0001$ \\
\hline Temperature $^{2}$ & -0.153 & 0.0228 & -6.72 & 0.0003 \\
\hline Ratio $^{2}$ & -44.92 & 11.64 & -3.86 & $<0.0001$ \\
\hline Source & Sum of squares & Degrees of freedom & F-statistics & $\mathrm{p}$-Value \\
\hline Means model & 3564.85 & 5 & 273.87 & $<0.00001$ \\
\hline Residual & 125.96 & 48 & & \\
\hline \multicolumn{5}{|c|}{$\begin{array}{l}\text { Glu } \cos e\left(g / 100 g_{D M}\right)=-392.71+15.76 \cdot T+153.05 \cdot \text { Ratio }-1.760 \cdot T \cdot \text { Ratio }-0.1530 \cdot T^{2}-44.92 \cdot \text { Ratio }^{2} \\
\mathrm{R}^{2}=0.966 ; \text { adjusted } \mathrm{R}^{2}=0.963\end{array}$} \\
\hline
\end{tabular}

Table 2 Design and results of RSM design for glucose release in the enzymatic hydrolysis of steam-exploded wheat straw

The proposed model (Equation (1)) describes the correlation between significant variables and the glucose production for enzymatic hydrolysis of steam-exploded wheat straw with Accellerase 1500 . The $R^{2}$-value was 0.966 , in good agreement with the adjusted $R^{2}$-value of 0.963 . The high $R^{2}$-value, 0.966 , indicates that the model was well adapted to the response.

$$
\begin{array}{r}
\text { Glucose }(g \text { per } 100 g D M)=-392.71+15.76 \times T+153.05 \times \text { Ratio }^{2} 1.760 \times T \times \text { Ratio }^{2} \\
-0.1530 \times T^{2}-44.92 \times \text { Ratio }^{2}
\end{array}
$$

The response surface plot for glucose released as a function of two factors (temperature and enzyme ratio) for a fixed pH value of 4 (level 1) is shown in Fig. 2.

The $P$-value of the adjusted model was lower than 0.00001 , indicating that the model is statistically valid. The $P$-values for temperature, ratio, the interaction ratioxtemperature, the temperature-squared and the ratio-squared were all lower than 0.0005 , demonstrating that they were the most important factors influencing glucose production. 
The statistical analysis demonstrated that $\mathrm{pH}$ is the least significant factor for glucose release with no interaction effect with temperature and enzyme ratio.

The temperature and the enzyme/substrate ratio are the most significant factors affecting glucose liberation in the enzymatic hydrolysis. In addition, an important effect of the interaction between dosage ratio and temperature was found.

These results are in agreement with the influence of temperature, $\mathrm{pH}$ and enzyme/substrate ratio on glucose release detailed in the previous section. The optimum values of the selected variables for glucose release, obtained by solving the regression equation, are: the higher enzyme dosage ratio $\left(0.5 \mathrm{~mL} \mathrm{~g}^{-1}\right.$ cellulose), the lower temperature $\left(50{ }^{\circ} \mathrm{C}\right)$ and the lower $\mathrm{pH}$ value (4) with an optimum glucose production of $34.6 \mathrm{~g}$ per $100 \mathrm{gDM}$.

The same trend was found by Cruz et al., 2011 in their optimization work on the enzymatic operating conditions of lignocellulosic material (banana peel ash) with Accellerase 1000 and Accellerase 1500 using a factorial design. They reported that temperature and dosage ratio are the most significant factors, with the greatest influence in the liberation of reducing sugars. The optimum operating conditions for maximum sugar liberation were $50{ }^{\circ} \mathrm{C}, \mathrm{pH} 4.5$ and 0.25 mLenzyme $\mathrm{g}^{-1}$ biomass intherangetested $\left(T=46-54{ }^{\circ} \mathrm{C} ; \mathrm{pH}=4-5\right.$; enzyme dosage ratio $=$ $0.15-0.35 \mathrm{~mL} \mathrm{~g}^{-1}$ biomass).

\section{Xylose release model}

The response surface quadratic model for xylose release and the corresponding statistical analysis of the model is presented in Table 3. The ANOVA analysis performed on the reduced model (Table 3 ) demonstrated that the model is valid $(P$-value $<0.0001)$. The ANOVA for model terms and its significance showed that the linear effect of ratio and the interactions $\mathrm{pH} \times$ temperature and ratioxtemperature were the most significant factors affecting enzymatic hydrolysis.

\begin{tabular}{|l|c|c|c|c|}
\hline \multirow{2}{*}{ Variable } & \multicolumn{4}{|c|}{ XYLOSE MODEL } \\
\cline { 2 - 5 } & Coefficient & Standard error & T-stat & P-Value \\
\hline Constant & 4.51 & 0.4306 & 10.47 & $<0.0001$ \\
\hline Ratio & 9.007 & 2.207 & 4.08 & 0.0002 \\
\hline $\mathrm{pH} \times$ Temperature & -0.0087 & 0.0017 & -5.20 & $<0.0001$ \\
\hline Ratio $\times$ Temperature & -0.1107 & 0.0393 & -2.82 & 0.0069 \\
\hline \multicolumn{5}{|c|}{} \\
\hline Source & Sum of squares & Degrees of freedom & F-statistics & p-Value \\
\hline Means model & 20.09 & 3 & 51.71 & $<0.0001$ \\
\hline Residual & 6.48 & 50 & & \\
\hline $\begin{array}{l}\text { Xylose }\left(g / 100 g_{D M}\right)=4.51+9.007 \cdot \text { Ratio-0.0087.pH·T-0.1107-RatioT } \\
\mathrm{R}^{2}=0.756 ; \text { adjusted } \mathrm{R}^{2}=0.742\end{array}$ \\
\hline
\end{tabular}

Table 3 Design and results of RSM design for xylose release in the enzymatic hydrolysis of steamexploded wheat straw

The proposed model for xylose release is presented in Equation (2). The R2-value of 0.756 indicates that the model fitted the experimental data reasonably well.

$$
\text { Xylose }(g \text { per } g D M)=4.51+9.007 \times \text { Ratio }-0.0087 \times p H \times T-0,1107 \times \text { Ratio } \times T
$$

The response surface plot for xylose released as a function of temperature and enzyme ratio for a fixed $\mathrm{pH}$ value of 4 (level 1 ) is shown in Fig. 3. 
The statistical analysis demonstrated that $\mathrm{pH}$ is the individual factor with the least significant effect on xylose release, although it presents a slight interaction effect with temperature. The enzyme/substrate ratio is the most significant factor affecting xylose liberation. In addition, an important effect of interaction between ratio and temperature is found. The temperature is not significant as an individual factor but it has an important interaction effect together with the enzyme dosage ratio. The optimum values of the variables for xylose release, obtained by solving the regression equation, are the higher enzyme dosage ratio $\left(0.5 \mathrm{~mL} \mathrm{~g}^{-1}\right.$ cellulose), a temperature close to the lower level $\left(51.4^{\circ} \mathrm{C}\right)$ and the lower $\mathrm{pH}$ value (4) with an optimum xylose production of $4.6 \mathrm{~g}$ per 100gDM.

\section{Model validation}

The optimum values of the selected variables for enzymatic hydrolysis of pretreated wheat straw were: $\mathrm{pH}=4$; enzyme ratio $=0.5 \mathrm{~mL} \mathrm{~g}^{-1}$ cellulose and $\mathrm{T}=50.0^{\circ} \mathrm{C}$ for glucose liberation and $\mathrm{pH}=4$; enzyme ratio $=0.5 \mathrm{~mL} \mathrm{~g}^{-1}$ cellulose and $\mathrm{T}=51.4^{\circ} \mathrm{C}$ for xylose release. To validate the model, these optimum values were tested in triplicate sets of experiments. The experimental responses for enzymatic hydrolysis obtained with the confirmatory experiments were $33.3 \pm 1.0$ $\mathrm{g}$ per $100 \mathrm{gDM}$ and $4.4 \pm 0.3 \mathrm{~g}$ per $100 \mathrm{gDM}$ for glucose and xylose release, respectively. These values are in good agreement with the predicted model values for glucose production of $34.6 \mathrm{~g}$ per $100 \mathrm{gDM}$ and xylose production of $4.6 \mathrm{~g}$ per $100 \mathrm{gDM}$, considering a $95 \%$ confidence range. This behaviour shows the adaptation of the model to the experimental results, confirming the validity and adequacy of the proposed models for glucose and xylose production in hydrolysates. In order to compare our enzymatic hydrolysis results under the best conditions with others reported in the literature a complete literature review was made. Table 4 summarizes the most remarkable operational conditions used by researchers, the raw material tested, and the sugar yield obtained in the enzymatic hydrolysis of lignocellulosic materials using Accellerase enzymes. As can be observed similar operational conditions have been tested by other researchers. Regarding sugar yield our reported values $(81 \%$ for glucose and $27 \%$ for xylose) are in the range found in the literature although the xylose production seems to be slightly lower. To enhance sugar liberation (mainly xylose) specific enzyme complexes with xylanase and xylanase/cellulose activity were supplemented to Accellerase 1500 , as is shown in the following section.

\begin{tabular}{|c|c|c|c|c|c|c|c|c|c|c|}
\hline Reference & $\begin{array}{c}\text { Raw } \\
\text { material }\end{array}$ & Pretreatment & $\begin{array}{c}\text { Enzym } \\
e\end{array}$ & $\mathrm{pH}$ & $t(h)$ & $\begin{array}{c}\mathrm{T} \\
\left({ }^{\circ} \mathrm{C}\right)\end{array}$ & $\begin{array}{c}\text { Enzyme } \\
\text { dosage ratio }\end{array}$ & $\begin{array}{c}\text { Glucose } \\
\text { yield }\end{array}$ & $\begin{array}{c}\text { Xylose } \\
\text { yield }\end{array}$ & $\begin{array}{l}\text { Reduce } \\
\text { sugar } \\
\text { yield }\end{array}$ \\
\hline 22 & $\begin{array}{l}\text { Rice } \\
\text { straw }\end{array}$ & $\begin{array}{l}\text { Alkaline } \\
\text { peroxide } \\
\text { method }\end{array}$ & $\begin{array}{l}\text { Ac. } 150 \\
0\end{array}$ & 5 & 72 & 50 & $0.3 \mathrm{~mL} / \mathrm{g}_{\text {cellulose }}$ & & & $81 \%$ \\
\hline 23 & $\begin{array}{l}\text { Banana } \\
\text { peel ash }\end{array}$ & $\begin{array}{c}\text { Acid } \\
\text { prehydrolysis }\end{array}$ & $\begin{array}{c}\text { Ac. } 150 \\
0\end{array}$ & 4,5 & 72 & 50 & $0.25 \mathrm{~mL} / \mathrm{g}_{\text {cellulose }}$ & & & $15^{a, b}$ \\
\hline 25 & $\begin{array}{l}\text { Corn } \\
\text { stover }\end{array}$ & $\begin{array}{l}\text { Milling (ball } \\
\text { mill) }\end{array}$ & $\begin{array}{l}\text { Ac. } 100 \\
0\end{array}$ & -- & 95 & 50 & $20 \mathrm{FPU} / \mathrm{g}_{\text {glucan }}$ & $52 \%^{\mathrm{b}}$ & $34 \%^{b}$ & \\
\hline 12 & $\begin{array}{l}\text { Wheat } \\
\text { straw }\end{array}$ & $\begin{array}{c}\text { Steam } \\
\text { explosion }\end{array}$ & $\begin{array}{l}\text { Ac. } 150 \\
0\end{array}$ & 5 & 72 & 50 & $8.2 \mathrm{mg} / \mathrm{g}$ protein & $6.2^{a, b}$ & $1.8^{a, b}$ & \\
\hline 24 & $\begin{array}{l}\text { Wheat } \\
\text { straw }\end{array}$ & $\begin{array}{c}\text { Steam } \\
\text { explosion }\end{array}$ & $\begin{array}{l}\text { Ac. } 100 \\
0 \\
\end{array}$ & 5 & 72 & 50 & $\begin{array}{c}36 \mathrm{mg}_{\text {protein }} / \mathrm{g} \\
\text { cellulose }\end{array}$ & $91 \%^{b}$ & $52 \%^{b}$ & \\
\hline This paper & $\begin{array}{l}\text { Wheat } \\
\text { straw }\end{array}$ & $\begin{array}{c}\text { Steam } \\
\text { explosion }\end{array}$ & $\begin{array}{l}\text { Ac. } 150 \\
0\end{array}$ & 4 & 96 & 50 & $0.5 \mathrm{~mL} / \mathrm{g}$ cellulose & $81 \%$ & $27 \%$ & \\
\hline
\end{tabular}

${ }^{a}$ Sugar concentration in $\mathrm{g} \mathrm{L}^{-1}$

${ }^{\mathrm{b}}$ Data reported in graphical from

Table 4 Comparison of operating conditions and sugar yield reported by other researchers in the enzymatic hydrolysis of lignocellulosic materials with Accellerase enzymes

\subsection{Effect of $X C$ and $X Y$ supplementation on enzymatic hydrolysis with Acellerase 1500}

\section{Experimental design}

This section reports on the effect of Accellerase XY (xylanase enzyme complex) and Accellerase XC (xylanase/cellulase enzyme complex) supplementation on the hydrolysis of 
pretreated wheat straw with Accellerase 1500. The aim of this supplementation is to enhance the cellulolytic activity by selection of a suitable enzyme cocktail that could be used as an effective tool for producing bioethanol efficiently from both cellulose and hemicellulose. Experiments were carried out at $3 \% \mathrm{w} / \mathrm{w}$ DM of steam-exploded wheat straw, $50{ }^{\circ} \mathrm{C}, 300 \mathrm{rpm}$, $0.5 \mathrm{~mL}$ Accellerase $1500 \mathrm{~g}^{-1}$ cellulose and $96 \mathrm{~h}$, modifying the $\mathrm{pH}$ and the enzyme/substrate

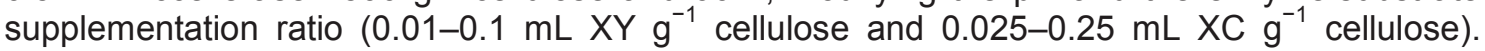
Experimental conditions were selected from the previously presented optimization study. Although it has been demonstrated that the $\mathrm{pH}$ is not significant for the enzymatic hydrolysis using Accellerase 1500, its influence on the addition of Accellerase XY and Accellerase XC has not been reported. As a result, it is necessary to include $\mathrm{pH}$ as a factor in the supplementation experiments. The range of dosage ratio of $X C$ and $X Y$ accessory enzyme was selected according to the recommendations suggested by the manufacturer. A total of 16 experiments were carried out with every supplementary enzyme at $\mathrm{pH}=4$ and $\mathrm{pH}=5$, with enzyme/ substrate dosage ratios of $0.01-0.1 \mathrm{~mL} \mathrm{~g}^{-1}$ cellulose for $X Y$ and $0.025-0.25 \mathrm{~mL} \mathrm{~g}^{-1}$ cellulose for XC. The set of experiments carried out and their operating conditions are shown in Table 5. For each experiment, three replicates were carried out. In a second step, a Student's t-test was used as statistical technique to check if the $\mathrm{pH}$ and/or complement loadings were significant factors; i.e. when the associated probability is less than 0.05 .

\begin{tabular}{|c|c|c|}
\hline Run & pH & $\begin{array}{c}\text { XC dosage rate } \\
\text { (mL/g } \text { cellulose) }\end{array}$ \\
\hline 1 & 4 & 0 \\
2 & 4 & 0.025 \\
3 & 4 & 0.125 \\
4 & 4 & 0.225 \\
5 & 5 & 0 \\
6 & 5 & 0.025 \\
7 & 5 & 0.125 \\
8 & 5 & 0.250 \\
\hline
\end{tabular}

\begin{tabular}{|c|c|c|}
\hline Run & pH & $\begin{array}{c}\text { XY dosage rate } \\
\text { (mL/g cellulose) }\end{array}$ \\
\hline 9 & 4 & 0 \\
10 & 4 & 0.01 \\
11 & 4 & 0.05 \\
12 & 4 & 0.1 \\
13 & 5 & 0 \\
14 & 5 & 0.01 \\
15 & 5 & 0.05 \\
16 & 5 & 0.1 \\
\hline
\end{tabular}

Table 5 Experimental design for enzymatic hydrolysis with Accellerase 1500 with accessory xylanase complements (Accellerase-XC and Accellerase- $\mathrm{XY}$ )

\section{pH effect}

Figure 4 shows the effect of enzyme cocktail supplementation ( $X C$ and $X Y$ ) on the enzymatic hydrolysis of Acellerase 1500 expressed as glucose and xylose production (g per $100 \mathrm{gDM}$ ), at different $\mathrm{pH}$ levels. The hydrolysis experiment carried out with Accellerase 1500 without supplementation was used as a control assay. The $\mathrm{pH}$ level significantly affects the production of glucose and xylose when Accellerase $\mathrm{XC}$ is used. The lower $\mathrm{pH}$ value $(\mathrm{pH}=4)$ allows the concentration of released glucose and xylose to be improved. For example, operating with an $\mathrm{XC}$ dosage ratio of $0.125 \mathrm{~mL} \mathrm{~g}^{-1}$ cellulose at $\mathrm{pH}=4$, the production of glucose and xylose reached are $41.0 \pm 2.6 \mathrm{~g}$ per $100 \mathrm{gDM}$ and $5.8 \pm 0.1 \mathrm{~g}$ per $100 \mathrm{gDM}$, respectively. This means an increase in glucose production of $32.2 \%$ and $15.9 \%$ for xylose production in comparison with the control assay (only Accellerase 1500). At the same dosage ratio but higher $\mathrm{pH}(\mathrm{pH}=5)$, glucose and xylose production decrease by $7.1 \%$ for glucose and $4.2 \%$ for xylose compared with operation at $\mathrm{pH}=4$. However, the $\mathrm{pH}$ effect was insignificant when $\mathrm{XY}$ supplementation was used, as can also be seen in Fig. 4. The maximum increases for glucose and xylose production when the $\mathrm{pH}$ was modified were $2.8 \%$ and $2.1 \%$, respectively. Similar levels of production of glucose and xylose were reported in the literature for enzymatic hydrolysis of steam-explodedwheat straw carried out with Accellerase 1500 in combination with endoxylanase and $\alpha$-L-arabinofuranosidase complements at $\mathrm{pH}=5$ (Alvira $\mathrm{P}$ et al., 2011).

From analysis of the present results, it can be concluded that the optimum $\mathrm{pH}$ value for both complements is $\mathrm{pH}=4$. This $\mathrm{pH}$ value gives a cost advantage since operating at lower $\mathrm{pH}$ requires less consumption of chemical products used in the preparation of buffer solution. Reducing the consumption of chemical products reduces the operating costs at scale up the hydrolysis process. 

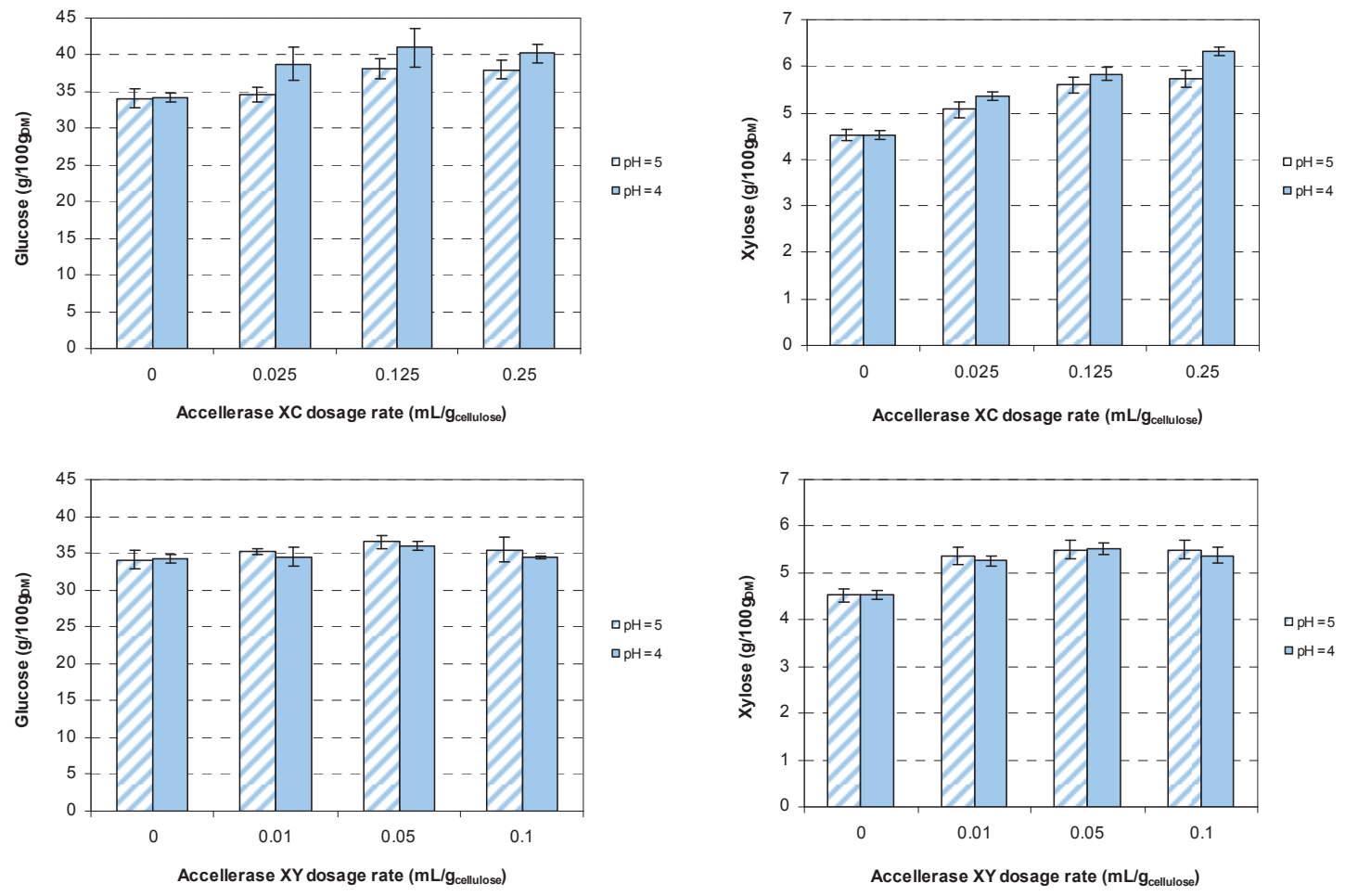

Figure 4 Effect of $X C$ and $X Y$ supplementation ratio on glucose and xylose production at different $\mathrm{pH}$ levels. Enzymatic hydrolysis was carried with a $3 \mathrm{w} / \mathrm{w} \% \mathrm{DM}$ of steam-exploded wheat straw $\left(210^{\circ} \mathrm{C}, 10 \mathrm{~min}\right)$, at $50{ }^{\circ} \mathrm{C}, 300 \mathrm{rpm}, 0,5 \mathrm{~mL}$ Accellerase 1500/gcellulose and $96 \mathrm{~h}$

\section{Effect of $X C$ and $X Y$ loadings}

As can be seen in Fig. 4, acellerase XC supplementation significantly improved the production of glucose and xylose, this effect being more obvious for low dosages. For a dosage ratio of $0.125 \mathrm{~mL} \mathrm{~g}^{-1}$ cellulose, glucose and xylose production increased by $11.8 \%$ and $23.6 \%$, respectively, compared with the control assay. On the other hand, higher production of xylose was obtained with higher $\mathrm{XY}$ supplement loading, but the increasing trend became less intense at high loading. This phenomenon may be because of the competition for productive sites between Accellerase 1500 and the Accellerase XY enzyme complex. These results are in agreement with previous results obtained for pretreated (aqueous ammonia soaking) corncob hydrolysis with enzyme complexes. In this work when the cellulose complex (Spezyme CP) was supplemented with xylanase $(0.67 \mathrm{mg}$ protein/g glucan), the $24 \mathrm{~h}$ yield of xylose increased by $26.5 \%$ (Zhang $M$ et al., 2010). These results suggest that the increase of glucose and xylose production at high enzymatic loadings is not significant enough to justify working with high complement concentrations.

\section{Statistical analysis: student t-test}

An analysis based on the t-test has been used to check statistically if the complement loading and the $\mathrm{pH}$ are significant factors in the enzymatic hydrolysis of steam-exploded wheat straw with Accellerase 1500. The results of the Student t-test analysis for a confidence level of $95 \%$ calculated with EXCEL software are shown in Table 6. A first step analyzes whether the $\mathrm{pH}$ value is a significant factor for the different accessory enzyme loadings (Table 6(a)) in the range tested. A second step also analyzes whether the accessory enzyme loading, at a fixed $\mathrm{pH}$ value, is an important variable for enzymatic hydrolysis (Table 6(b)). Regarding the $\mathrm{pH}$ factor, when the Acellerase XC complement was added, Table 6(a) shows that the probability associated with the t-test, for both glucose and xylose production, was lower than 0.05 for all cases analyzed. Thismeans that $\mathrm{pH}$ is a significant factor for enzymatic hydrolysis when XC complement is used, obtaining higher sugar production when operating at a lower $\mathrm{pH}(\mathrm{pH}=4)$. In contrast, for the additive $\mathrm{XY}$, the P-values for glucose and xylose are higher than 0.05 . This result indicates that $\mathrm{pH}$ is not an important factor for enzymatic hydrolysis, resulting in similar 
glucose and xylose production levels to those obtained when no complements were used (the mean values of sugar production for the samples compared are very close). These results suggest that the lower $\mathrm{pH}(\mathrm{pH}=4)$ is desirable for higher sugar liberation and for a reduction in the addition of chemical additives (more economical solution) when enzymatic hydrolysis with $\mathrm{XC}$ and $\mathrm{XY}$ complements is carried out. For the enzyme loading factor, it can be observed that for the XC complement (Table $6(\mathrm{~b}))$ at $\mathrm{pH}=4$, the $P$-values for glucose production are in all cases higher than 0.05 . This result suggests that an increase in XC loading in the range tested is not significant in improving the glucose release. However, for xylose release, an increment in the $\mathrm{XC}$ dosage ratio is significant when the dosage ratio is increased from 0.025 to $0.250 \mathrm{~mL}$ $\mathrm{g}-1$ cellulose $(P$ value $=0.000014<0.05)$. The increase in xylose production is from $5.4 \pm 0.1 \mathrm{~g}$ per $100 \mathrm{gDM}$ to $5.9 \pm 0.1 \mathrm{~g}$ per $100 \mathrm{gDM}$ operating with $\mathrm{XC}$ dosage ratios of 0.025 and $0.250 \mathrm{~mL}$ $\mathrm{g}^{-1}$ cellulose, respectively. Combining the effect of $X C$ enzyme loading on glucose and xylose liberation, an optimum dosage ratio of $0.125 \mathrm{~mL} \mathrm{~g}^{-1}$ cellulose is proposed. A higher enzyme dosage ratio would increase the cost of the enzymatic process with only an insignificant increase in sugar production. Using the additive $X Y$ at $p H=4$ (Table $6(b)$ ), the $P$-values for glucose and xylose are in all cases higher than 0.05 . This result indicates that $X Y$ loading will not be an important factor for enzymatic hydrolysis, giving similar glucose and xylose production levels in the range of enzyme loadings tested. From an economic point of view, a low dosage ratio of $X Y\left(0.01 \mathrm{~mL} \mathrm{~g}^{-1}\right.$ cellulose $)$ can be selected. Finally, a Student $t$-test was carried out to check which of the two complements allows the higher production of sugars. In this case, the probability associated with the $t$-test is less than 0.05 . This result indicates that the additive Acellerase-XC offers higher yields than Acellerase-XY. Student- $t$ analysis revealed that the accessory enzyme loading is not a significant factor in enzymatic hydrolysis with Accellerase 1500. Similar results were reported by Zhang et al.26 in their study of the enzymatic hydrolysis of lignocelluloses by optimizing enzyme complexes (mixture of xylanase and pectinase). Lower $\mathrm{pH}$ levels increase the concentration of glucose and xylose released when the $\mathrm{XC}$ complement is used. No pH effect was observed for the $X Y$ supplementation. Student- $t$ analysis corroborated this experimental result. XC supplementation was more effective in promoting the hydrolysis of cellulose and hemicellulose. The supplementation of XC at $0.125 \mathrm{~mL} \mathrm{~g}^{-1}$ cellulose could increase the production of glucose and xylose by $11.8 \%$ and $23.6 \%$, respectively, compared with enzymatic hydrolysis using only Accellerase 1500. Supplementation with xylanases (Accellerase- $\mathrm{XC}$ and Accellerase- $\mathrm{XY}$ ) has demonstrated that the enzymatic hydrolytic efficiency can be improved. Several enzyme complexes reported in the literature that include xylanases in their formulation have effectively promoted the hydrolysis of cellulose and hemicelluloses in agricultural materials (Lin ZX et al., 2011; Zhang M et al., 2010) 
(a) Effect of $\mathrm{pH}$ on enzymatic hydrolysis with Accellerase 1500 with enzyme supplements

\begin{tabular}{|c|c|c|c|c|c|c|c|c|c|c|c|}
\hline pH & $\begin{array}{l}\text { Acellerase } \\
\text { XC dosage } \\
\text { rate }(\mathrm{ml} / \mathrm{g} \\
\text { cellulose) }\end{array}$ & $\begin{array}{c}\text { Glucose } \\
\text { (g/100g } \\
\text { DM) }\end{array}$ & $\begin{array}{l}\text { p-value } \\
\text { t- test * } \\
\text { (Glucose) }\end{array}$ & $\begin{array}{c}\text { Xylose } \\
\text { (g/100g } \\
\text { DM) }\end{array}$ & $\begin{array}{l}\text { p-value } \\
\text { t- test * } \\
\text { (Xylose) }\end{array}$ & pH & $\begin{array}{l}\text { Acellerase } \\
\text { XY dosage } \\
\text { rate }(\mathrm{ml} / \mathrm{g} \\
\text { cellulose) }\end{array}$ & $\begin{array}{c}\text { Glucose } \\
\text { (g/100g } \\
\text { DM) }\end{array}$ & $\begin{array}{c}\text { p-value } \\
\text { t- test * } \\
\text { (Glucose) }\end{array}$ & $\begin{array}{c}\text { Xylose } \\
\text { (g/100g } \\
\text { DM) }\end{array}$ & $\begin{array}{l}\text { p-value } \\
\text { t- test } * \\
\text { (Xylose) }\end{array}$ \\
\hline 4 & \multirow{2}{*}{0.025} & $38.80 \pm 2.30$ & \multirow{2}{*}{0.000816} & $5.36 \pm 0.08$ & \multirow{2}{*}{0.001184} & 4 & \multirow{2}{*}{0.01} & $34.52 \pm 1.27$ & \multirow{2}{*}{0.213700} & $5.26 \pm 0.09$ & \multirow{2}{*}{0.415000} \\
\hline 5 & & $34.61 \pm 0.98$ & & $5.07 \pm 0.17$ & & 5 & & $35.24 \pm 0.46$ & & $5.36 \pm 0.19$ & \\
\hline 4 & \multirow{2}{*}{0.125} & $41.03 \pm 2.64$ & \multirow{2}{*}{0.031936} & $5.84 \pm 0.14$ & \multirow{2}{*}{0.013721} & 4 & \multirow{2}{*}{0.05} & $36.02 \pm 0.59$ & \multirow{2}{*}{0.312560} & $5.52 \pm 0.14$ & \multirow{2}{*}{0.541490} \\
\hline 5 & & $38.11 \pm 1.42$ & & $5.59 \pm 0.17$ & & 5 & & $36.49 \pm 0.92$ & & $5.50 \pm 0.19$ & \\
\hline 4 & \multirow{2}{*}{0.250} & $40.21 \pm 1.21$ & \multirow{2}{*}{0.000003} & $6.32 \pm 0.10$ & \multirow{2}{*}{0.000007} & 4 & \multirow{2}{*}{0.1} & $34.42 \pm 0.24$ & \multirow{2}{*}{0.208000} & $5.37 \pm 0.17$ & \multirow{2}{*}{0.349450} \\
\hline 5 & & $38.00 \pm 1.21$ & & $5.73 \pm 0.18$ & & 5 & & $35.44 \pm 1.64$ & & $5.50 \pm 0.21$ & \\
\hline
\end{tabular}

(b) Effect of supplementation dosage rate on enzymatic hydrolysis with Accellerase 1500 with enzyme supplements

\begin{tabular}{|c|c|c|c|c|c|c|c|c|c|c|c|}
\hline $\mathbf{p H}$ & $\begin{array}{l}\text { Acellerase } \\
\text { XC dosage } \\
\text { rate }(\mathrm{ml} / \mathrm{g} \\
\text { cellulose) }\end{array}$ & $\begin{array}{c}\text { Glucose } \\
(\mathrm{g} / 100 \mathrm{~g} \\
\mathrm{DM})\end{array}$ & $\begin{array}{l}\text { p-value } \\
\text { t- test * } \\
\text { (Glucose) }\end{array}$ & $\begin{array}{c}\text { Xylose } \\
\text { (g/100g } \\
\text { DM) }\end{array}$ & $\begin{array}{l}\text { p-value } \\
\text { t- test * } \\
\text { (Xylose) }\end{array}$ & pH & $\begin{array}{l}\text { Acellerase } \\
\text { XY dosage } \\
\text { rate }(\mathrm{ml} / \mathrm{g} \\
\text { cellulose) }\end{array}$ & $\begin{array}{c}\text { Glucose } \\
\text { (g/100g } \\
\text { DM) }\end{array}$ & $\begin{array}{l}\text { p-value } \\
\text { t- test } * \\
\text { (Glucose) }\end{array}$ & $\begin{array}{c}\text { Xylose } \\
\text { (g/100g } \\
\text { DM) }\end{array}$ & $\begin{array}{l}\text { p-value } \\
\text { t- test * } \\
\text { (Xylose) }\end{array}$ \\
\hline \multirow{6}{*}{4} & 0.125 & $41.03 \pm 2.64$ & \multirow{2}{*}{0.106558} & $5.84 \pm 0.14$ & \multirow{2}{*}{0.683000} & \multirow{6}{*}{4} & 0.05 & $36.02 \pm 0.59$ & \multirow{2}{*}{0.103701} & $5.52 \pm 0.14$ & \multirow{2}{*}{0.206300} \\
\hline & 0.025 & $38.80 \pm 2.30$ & & $5.36 \pm 0.08$ & & & 0.01 & $34.52 \pm 1,27$ & & $5.26 \pm 0.09$ & \\
\hline & 0.250 & $40.21 \pm 1.21$ & \multirow{2}{*}{0.206515} & $6.32 \pm 0.10$ & \multirow{2}{*}{0.000014} & & 0.1 & $34.42 \pm 0.24$ & \multirow{2}{*}{0.782000} & $5.37 \pm 0.17$ & \multirow{2}{*}{0.294300} \\
\hline & 0.025 & $38.80 \pm 2.30$ & & $5.36 \pm 0.08$ & & & 0.01 & $34.52 \pm 1.27$ & & $5.26 \pm 0.09$ & \\
\hline & 0.125 & $41.03 \pm 2.64$ & \multirow{2}{*}{0.492700} & $5.84 \pm 0.14$ & \multirow{2}{*}{0.795000} & & 0.05 & $36.02 \pm 0.59$ & \multirow{2}{*}{0.191200} & $5.52 \pm 0.14$ & \multirow{2}{*}{0.798860} \\
\hline & 0.250 & $40.21 \pm 1.21$ & & $6.32 \pm 0.10$ & & & 0.1 & $34.42 \pm 0.24$ & & $5.37 \pm 0.17$ & \\
\hline
\end{tabular}

$* t-$ Student test for a confidence level of $95 \%$

Table 6 Effect of $\mathrm{pH}$ and supplementation dosage rate on enzymatic hydrolysis with Accellerase 1500 with XC and XY accessory enzymes. $\mathrm{t}$ - Student analysis

\section{CONCLUDING REMARKS}

A complete and systematic study of the influence of several operational parameters on enzymatic hydrolysis of steamexploded wheat straw to maximize sugar yield using Accellerase 1500 (main activity cellulase) and its combination with specific xylanase complements (Accellerase- $\mathrm{XC}$ and Accellerase- $\mathrm{XY}$ ) has been made. Temperature, $\mathrm{pH}$, enzyme/substrate ratio, dry matter content, agitation rate and reaction time were identified as critical factors affecting the hydrolysis step. All of them were considered in this work, unlike previous published works. Although similar operational conditions of enzymatic hydrolysis of lignocellulosic materials with Accellerase 1500 have been investigated by other researchers, as far as is known, the use of experimental design approaches (RSM methodology and Student's t-test) to optimize the operational variables when specific complements (Accellerase $X C$ and Accellerase $\mathrm{XY}$ ) are supplemented to Accellerase 1500 has not been reported. Preliminary experiments and a literature review were used to set the dry matter content at $3 \% \mathrm{w} / \mathrm{w} \mathrm{DM}$, agitation rate at 300 $\mathrm{rpm}$ and reaction time at $96 \mathrm{~h}$. In order to determine the optimal combination of the other three factors operating with Accellerase 1500, the response surface methodology (RSM) and multiple regression methods were used. Statistical results from ANOVA analysis demonstrated that enzymatic hydrolysis was clearly improved by optimizing temperature and enzyme/substrate ratio. The optimum conditions for high glucose and xylose release were $0.5 \mathrm{~mL} \mathrm{~g}^{-1}$ cellulose, $50^{\circ} \mathrm{C}$ and $\mathrm{pH} 4$. Model validation of the optimum operating conditions showed good agreement between experimental results $(33.3 \pm 1.0 \mathrm{~g}$ glucose per $100 \mathrm{~g} \mathrm{DM}$ and $4.4 \pm 0.3 \mathrm{~g}$ xylose per 100 $\mathrm{g} \mathrm{DM}$ ) and the predicted responses for a confidence level of $95 \%$ (34.6 g glucose per $100 \mathrm{~g}$ DM and $4.5 \mathrm{~g}$ xylose per $100 \mathrm{~g} \mathrm{DM}$ ).

The effect of the addition of accessory xylanase enzyme complexes (Accellerase- $X C$ and Accellerase-XY) to Accellerase 1500 to improve sugar yield has been studied. The influence of $\mathrm{pH}$ and enzyme loading were analyzed statistically with a Student-t significance test. XC supplementation was more effective in promoting the hydrolysis of cellulose and hemicellulose. 
Supplementation with $\mathrm{XC}$ at $0.125 \mathrm{~mL} \mathrm{~g}^{-1}$ cellulose increased the yields of glucose and xylose by $11.8 \%$ and $23.6 \%$, respectively, compared with enzymatic hydrolysis using only Accellerase 1500.

This investigation involves an advance in research on hydrolysis optimization with the goal of increasing the efficiency of converting biomass materials, such as wheat straw, into glucose and xylose sugars. However, more research is required to improve the hydrolysis step before commercialization of the ethanol production process. Better pretreatment techniques, optimizing enzyme complex composition or reducing enzymatic dosages are approaches for increasing efficiency and decreasing the cost of cellulose and hemicellulose enzymatic hydrolysis.

\section{ACNOWLEDGEMENTS}

The authors would like to thank the Ministerio de Ciencia e Innovación (CTQ2006-15217), the Instituto Tecnológico de Castilla y León (VA-15-C2-1) and the Junta de Castilla y León (GRE233) for their financial support of this project.

\section{REFERENCES}

Alvira, P., Negro, M.J., Ballesteros, M., 2011. Effect of endoxylanase and a-Larabinofuranosidase supplementation on the enzymatic hydrolysis of steam exploded wheat straw. Bioresour. Technol., 102, 4552-4558.

Alvira, P., Negro, M.J., Sáez, F., Ballesteros, M., 2010. Application of a microassay method to study enzymatic hydrolysis of pretreated wheat straw. J Chem Technol Biotechnol 85:12911297.

Alvira, P., Tomás-Pejó E., Ballesteros, M., Negro M.J., 2010. Pretreatment technologies for an efficient bioethanol production process based on enzymatic hydrolysis: a review. Bioresour. Technol., 101, 4851-4861.

Banerjee, G., Scott-Craig, J.S., Walton, J.D., 2010. Improving enzymes for biomass conversion: a basic research perspective. Bioenerg. Res., 3, 82-92.

Bellido, C., Bolado, S., Coca, M., Lucas, S., González-Benito, G., García-Cubero, M.T., 2011. Effect of inhibitors formed during wheat straw pretreatment on etanol fermentation by Pichia stipitis. Bioresour. Technol., 102, 10868-10874.

Berlin, A., Maximenko, V., Gilkes, N., Saddler, J., 2007. Optimization of enzyme complexes for lignocellulose hydrolysis. Biotechnol. and Bioengin., 97, 287-296.

Cruz, K., Suárez, C., Gómez, A., Otálvaro, B., 2011. Optimización de las condiciones de operación de la hidrólisis enzimática sobre el material lignocelulósico de la planta de banano y su fruto. V Simposio Internacional de Biofábricas, Colombia.

Fang, H., Zhao, C., Song, X.Y., 2010. Optimization of enzimatic hydrolysis of steam-exploded corn stover by two approaches: Response surface methodology or using cellulase from mixed cultures of Trichoderma reese RUT-C30 and Aspergillus niger NL02. Bioresour. Technol., 101, 4111-4119.

Galbe, M., Zacchii, G., 2002. A review of the production of ethanol from softwood. Appl. Microbiol. Biotecnol., 59, 618-628.

García, M.T., Bolado, S., González, G., Catalina, I., Miranda, A., 2008. Comparison of ozonolysis and steam explosion of wheat straw as pretreatments to obtain bioethanol. In Proceedings of the 10th International Chemical and Biological Engineering Conference (Chempor 2008). Eugénio C. Ferreira and Manuel Mota, eds., Braga, pp. 964-970. 
García-Cubero, M.T., Marcos, M., Bolado, S., Coca, M., González- Benito, G., 2010. Optimization of operating conditions in enzymatic hydrolysis of pretreated lignocellulosic materials. Chem Eng Trans 21, 1285-1290.

Gusakov, A.V., Salanovich, T.N., Antonov, A.I., Ustinov, B.B., Okunev, O.N., Burlingame, R., Emalfarb, M., Baez, M., Sinitsyn, A., 2007. Design of highly efficient cellulase mixtures for enzymatic hydrolysis of cellulose. Biotechnol. and Bioengin., 97, 1028-1038.

Lin, Y., Tanaka, S., 2006. Ethanol fermentation from biomass resources: current state and prospects. Appl. Microbiol. Biotecnol., 69, 627-642.

Lin, L., Yang, R., Liu, Y., Jiang, W., 2010. In-depth investigation of enzymatic hydrolysis of biomass wastes based on three major components: Cellulose, hemicellulose and lignin. Bioresour. Technolo., 101, 8217-8223.

Lin, Z.X., Zhang, H.M., Ji, X.J., Chen, J.W., Huang, H., 2011. Hydrolytic enzyme of cellulose for complex formulation applied research. Appl. Biochem. Biotechnol., 164, 23-33.

National Renewable Energy Laboratory (NREL), 1995. Chemical Analysis and Testing Laboratory Analytical Procedures: LAP-002, LAP-003, LAP-004. NREL, Golden, CO, USA. < http://www.eere.energy.gov/biomass/analytical procedures.html>.

Öhgren, K., Bura, R., Saddler, J., Zacchi, G., 2007. Effect of hemicellulose and lignin removal on enzymatic hydrolysis of steam pretreated corn stover. Bioresour. Technol., 98, 25032510.

Sarkar, N., Ghosh, S.k., Bannerjee, S., Aikat, K., 2012. Bioethanol production from agricultural wastes: an overview. Renewable Energy 37, 19-27.

Sun, Y., Cheng, J., 2002. Hydrolysis of lignocellulosic materials for ethanol production: a review. Bioresour. Technol., 83, 1-11.

Tabka, M.G., Herpoël-Gimbert, I., Monod, F., Asther, M., Sigoillot, J.C., 2006. Enzymatic saccharification of wheat straw for bioethanol production by a combined cellulose xylanase and feruloyl esterase treatment. Enzyme Microb. Technol., 39, 897-902.

Talebnia, F., Karakashev, D., Angelidaki, I., 2010. Production of bioethanol from wheat straw: an overview on pretreatment, hydrolysis and fermentation. Bioresour. Technol., 101, 47444753.

Tu, M., Zhang, X., Paice, M., MacFarlane, P., Saddler, J.N., 2009. The potential of enzyme recycling during the hydrolysis of a mixed softwood feedstock. Bioresour. Technol., 100, 6407-6415.

Wingren, A., Galbe, M., Roslander, C., Rudolf, A., Zacchi, G., 2005.Effect of reduction in yeast and enzyme concentrations in a simultaneous-saccharification-and fermentation- based bioethanol process: technical and economic evaluation. Appl. Biochem. Biotechnol., 121$124,485-499$.

Zaldivar, J., Nielsen, J., Olsson, L., 2001. Fuel ethanol production from lignocellulose: a challenge for metabolic engineering and process integration. Appl. Microbiol. Biotechnol., 56, 17-34.

Zhang, M., Su, R., Qi, W., He, Z., 2010. Enhanced enzymatic hydrolysis of lignocellulose by optimizing enzyme complex. Appl. Biochem. Biotechnol., 160, 1407-1414.

Zhou, K., Wang, Y-H., Chu, J., Zhuang, Y-P., Zhang, S-L., 2009. Optimization of cellulase mixture for efficient hydrolysis of steam-exploded corn stover by statistically design experiments. Bioresour. Technol., 100, 819-825. 
